\title{
MÚZEUMPEDAGÓGIAI FOGLALKOZÁS AZ IPOO-MODELL TÜKRÉBEN
}

Szerzők:

Aranyi Fruzsina

Eszterházy Károly Egyetem

Első szerző e-mail címe: aranyifr@gmail.com
Lektorok:

Dr. Koncz István

Professzorok az Európai Magyarországért

Egyesület

Dr. Mező Katalin

Debreceni Egyetem

Aranyi Fruzsina (2018): Múzeumpedagógiai foglalkozás az IPOO-modell tükrében.

Különleges Bánásmód, IV. évf. 2018/2. szám, 27-35. DOI 10.18458/KB.2018.2.27

\begin{abstract}
Absztrakt
A látogatóbarát múzeumi szemléletmód elterjedésével a múzeumi szakemberek kiállitásaikkal igyekeznek minél szélesebb látogatói réteget megszólitani. Ehhez szükséges a kiállitások szakszerü interpretációja a különbözö korosztályok számára. Így mindinkább felértékelödik mind a múzeumpedagógusok szerepe, mind a múzeum, mint non-formális oktatótér fajsúlyossága. Egy-egy kiállitás jellegét azonban bizonyos esetben nagyban befolyásolhatja a kiállitótér struktúrája is. A Debreceni Irodalom Háza öt kisebb egységre tagolt hosszú, egyenes tér, melyben az Álmodó magyarok címü állandó irodalmi kiállítás található. Ebben a térben jelent meg elszórtan a REJTÖzködö Irodalom címü idöszaki kiállitás. A kiállitótér zegzugossága kiváló lehetöséget biztositott egy mozaik szerü elrendezésre, s ezáltal egy játékositott múzeumpedagógiai foglalkozásra. Tanulmányunkban ezt a módszert vizsgáljuk meg az IPOO-modell tükrében. A módszer a tanulás hatékonyabbá tételét célozza, és kiválóan alkalmazható non-formális oktatási környezetben is, ahol a tanulás a kiállitás által közvetített információk meglétét takarja.
\end{abstract}

Kulcsszavak: non-formális oktatási környezet, múzeumpedagógia, játékosítás, látogatóbarát múzeumok, IPOO-modell

Diszciplina: pedagógia

\section{Abstract}

With the spread of the visitor friendly museum approach the professionals of the museum strive to address a visitor layer as wide as possible. It requires the professional interpretation of exhibitions for the different ages. Thus, both the role of museum pedagogues and the museums as non-formal education space are appreciated increasingly. However, the nature of an exhibition also may be influenced in certain cases by the structure of the exhibition space. The Literature House of Debrecen is a long straight space divided into five smaller units, in which the permanent literature exhibition of Dreaming Hungarians can be found. The periodical exhibition with the title of 'REJTÖzködö Irodalom' appeared in this space in a scattered way. The character of the exhibition space provided an excellent possibility for a mosaic layout and in this way for a gamified musem pedagogical activity. In our study this method is examined in the light of the IPOO-model. The aim of the method is how to make the learning more efficient and it can also be used in an excellent way in the non-formal 
education environment where learning covers the presence of pieces of information conveyed by the exhibition.

Keywords: the non-formal education, museum pedagogy, gamification, visitor friendly museums, IPOO-model

\section{Discipline: pedagogy}

\section{Bevezetés - A múzeumok összetett szerepe}

Az élethosszig tartó tanulás szemléletének térnyerése hatására a formális oktatási környezet mellett egyre fontosabb szerepet tölt be a non-formális oktatási környezet, így komoly látogatói igény mutatkozik a múzeumokban nyújtott pedagógiai munkára. Ezért különös fontosságú a közgyüjteményekben dolgozó múzeumpedagógusok szerepe. A múzeumok feladatáról szóló diskurzusban jól látszik, hogy a szakmát megosztja, mit tekintsenek elsődleges feladatuknak: a tudományos munka felmutatását, vagy pedig annak a látogatókhoz való eljuttatását. (Káldy, Kárpáti és Szirmai, 2010) Korábban a múzeumok célja nem a lehető legszélesebb látogatói réteg megszólítás volt. A modern múzeumok elterjedésével egy időben a szellemi elitet célozták meg a kiállítások, és a múzeumi szakemberek magától értetődőnek tekintették, hogy kiállítási koncepcióikat a látogatók megértik. Ebben az időszakban a kiállításokban alig jelenítettek meg tablókat, csak mütárgycédulákat. Mára azonban egyre inkább meggyökeresedik az a szemlélet, hogy a múzeumok fennmaradásának, látogatottságának záloga, hogy kielégítsék a társadalom igényét és kiállításaikban a társadalmat foglalkoztató kérdésekre reflektáljanak oly módon, hogy ne csak egy kitüntetett réteget, hanem a különböző korosztályokat mind sikerrel meg tudják szólítani. „A kiállítás megjeleníthet új tudományos eredményeket, bemutathat szakmai körökben nagy figyelmet keltő tárgyakat, de ha nem képes elgondolkodtatni, elbüvölni és érdekes, fontos ismeretekkel ellátni látogatóit, nem tekinthető sikeresnek." (Kárpáti és Vásárhelyi, 2013) Ezekhez a színes látogatói elvárásokhoz nem csak a kiállítás témáját, tartalmát és megjelenési formáját kell igazítani, hanem a pedagógiai módszereket is, amivel a múzeumpedagógusok közelebb viszik a látogatói csoportokhoz a tartalmat. Diák csoportok esetében a foglalkozásoknak illeszkedniük kell a közgyüjtemények anyagán túl a diákok korosztályi sajátosságához, de a NAT-hoz, a kerettantervhez és a helyi tantervhez is. Azonban ez az illeszkedés nem jelent egy-egy foglalkozás esetében akkora kötöttséget, mint jelentene formális oktatási környezetben egy iskolai tanóra keretében. A múzeumpedagógusoknak ugyanis nem kell számolniuk a kötött tananyaggal, sem egymásra épülő tanórákkal, sem előre meghatározott óraszámmal, ezért nagyobb szabadsággal alkalmazhatnak foglalkozásaik során nem tradicionális pedagógiai módszereket, melyek előkészítése kifejezetten időigényes. (Aranyi, 2017) Bizonyos esetekben a kiállítótér erősen meghatározza a kiállítás formáját és a látogatói befogadást is. Tanulmányunkban a továbbiakban a Debreceni Irodalom Háza szerkezeti adottságairól beszélünk a benne található állandó kiállítás tükrében.

\section{A kiállítótér jellegének hatása a kiállítás megjelenésére és a tartalom interpretálására}

A XVII. század végén épült tipikus cívis ház, ami a kiállításoknak helyet ad, az 1822-es átalakítást követően Verbkommando lett, 1829-től pedig kaszárnyának használták. Hogy betölthesse ezt a funkciót, kibővítették, fegyvertartó és istálló épült a hátsó udvarra. Az idők folyamán használták lakóépületnek, mentőállomásnak és irodának is. 1980-ban az Országos 
Müemléki Főfelügyelőséggel egyeztetve megkezdődött a helyreállítása. Legány Péter tervei nyomán mind a múemléki jelleget, mind a múzeumi funkciót szem elött tartva újították fel. Az épület azt a légkört idézi, amiben a szobrász, Medgyessy Ferenc és családja élt. A régi müemléki szárnyat modern, tetővilágításos kiállítócsarnokokat és szabadtéri szoborparkot magába foglaló Emlékmúzeum őrzi a Déri Múzeum 1921-1976 között gyüjtött Medgyessyanyagát, valamint az 1977-ben átvett hagyatékot. (Sz.Kürti Katalin, 2006) Az épületegyüttes jobb szárnyában Álmodó magyarok - Történetek Debrecen irodalmából címmel 2014-ben nyílt meg az egykori Debreceni Irodalmi Múzeum, a mai Debreceni Irodalom Háza állandó kiállítása, ami öt nagy egységre tagolódik.

Csokonai szobájában egy számítógépes technikával támogatott költői teret járhat be a látogató. A kiállítás koncepciója a mindennapi élet és a költői lét kettősségére épít. A látogató egy szekrényen keresztül jut be ebbe a térbe, ami a mindennapoktól való elkülönülés helyszíneként jelenik meg. A kiállítás reflektál arra a szobára, amit Csokonai egyfajta alkotótérként álmodott meg magának. A tér egyik domináns falfelületét elfoglaló falfestmény a költő szobáját is díszítő falfestményről fennmaradt leírások nyomán született meg.

A következő térben a Csokonai Kör kiállítása található. A kör volt Debrecenben az első egyesület, ami tudatosan törekedett helytörténeti és irodalmi relikviák gyüjtésére. Az így létrejött gyüjtemény képezte az 1902-ben megnyílt Városi Múzeum kiállításának anyagát. A tér mind berendezésében, mind a tárgyanyagában megidézi ezt a korszakot.

Az Oláh Gábor-szoba Debrecen egyik legjelentősebb szépírójának állít emléket, akinek a nevét az 1910-es években együtt emlegették Ady Endréével. Az idő előre haladásával azonban jelentősége és a hazai irodalmi életre gyakorolt hatása egyre csökkent. Ezzel párhuzamosan visszahúzódott a saját világába. A szoba ezt a szövegekbe zárt életet jeleníti meg egy szük, puritán, sötét térben, aminek a közepén található félgömb alakú tükörről verődik szét a szélrózsa minden irányába Oláh Gábor költészete.

A Könyvek termének falán függő könyvekbe lapozva interaktív és játékos módon ismerhetjük meg azokat a szépírókat, akik a 19. és a 20. században Debrecenhez kötődtek.

A Látványok termében pedig olyan irodalmi relikviák találhatók, melyek nem csak dokumentációs, hanem esztétikai értékük miatt is kiemelnek, mint például Ady Endre tolla, vagy Szabó Magda tükre. A kiállítást színházterem és pihenő teszi teljessé. (Lakner, 2014)

Az így rendelkezésünkre álló szerkezeti és tartalmi adottságok figyelembe vételével az állandó kiállításra úgy épült rá a REJTÖzködő Irodalom című időszaki kiállítás, hogy annak elemei nem álltak szoros párbeszédben az állandó kiállítással. Mégsem különültek el hivalkodóan tőle, hanem az öt kisebb térre tagolt épületben több ponton elszórtan jelenik meg. Ezt a töredékességet teszik koherenssé a Rejtő Jenő müveiből származó idézetekkel ellátott lábnyomok, amiket követve a látogató kognitív tudatában az időszaki kiállítás egésszé áll össze. Ilyen formán az állandó kiállítás anyaga, mint díszlet öleli körül az időszaki kiállítást úgy, hogy mind az állandó, mind az időszaki kiállítás önmagában értelmezhető egészet alkot, s egyik értelmezés sem hat zavaróan a látogatóra. Az így megkonstruált különleges tér újfajta befogadói attitüdöt követel meg, és új szemléletmódot vár el a múzeumpedagógustól is. A kiállítás interpretálásához igyekeztünk olyan módszert választani, ami leginkább megfelel a tér, a tartalom és a látogatók igényeinek. 


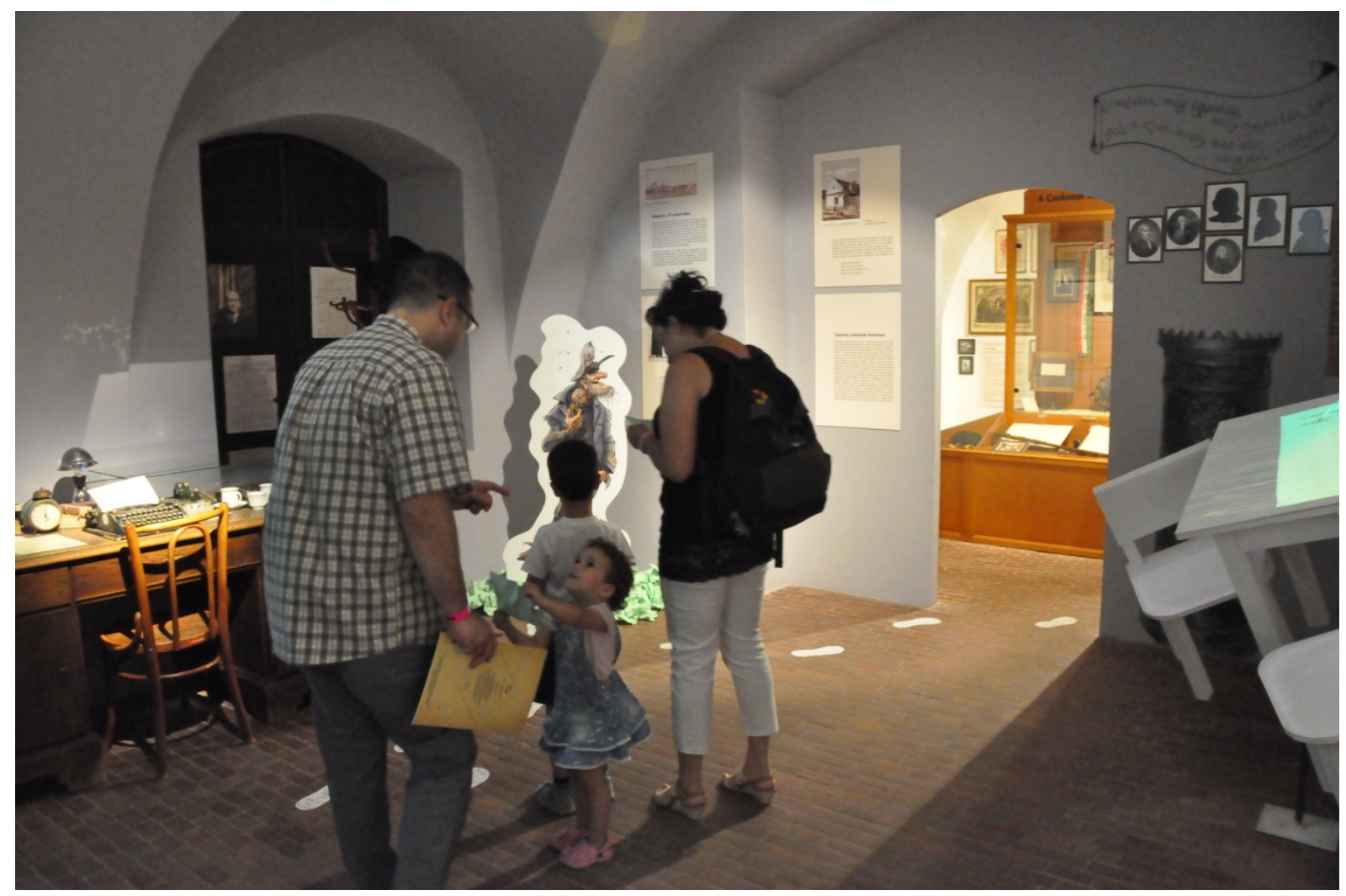

1.kép. REJTÖzködö Irodalom címü időszaki kiállitás. Fotó: Aranyi Fruzsina

\section{Egy mozaikszerü időszaki kiállítás}

Egy ilyen kaliberü tömegeket megmozgatni és szórakoztatva nevelni képes kiállítás, aminek szerves része a múzeumpedagógiai foglalkozás, nem jöhetett volna létre, ha nincs folyamatos párbeszéd a kiállítás kurátora és a múzeumpedagógus között. (Janes, 2009) Az együtt gondolkodás már a koncepció formálódása idején megkezdődött, és ennek eredményeképp olyan kiállítás született, ami tartalmában minden szakmai kritériumnak megfelel úgy, hogy közben formájában a pedagógiai szempontokat is figyelembe veszi. De meg tudtunk felelni azoknak az elvárásoknak is, amit a Rejtő Jenő müveit olvasó közönség táplált a kiállítással kapcsolatban.

Hová tűnt Rejtő Jenő? című múzeumpedagógiai foglalkozásunk története szerint „Rejtő Jenőt 1938-ban még látták Salamon Béla és Karinthy Frigyes társaságában, amint egy Siófokon készült fotó is tanúsít. Ezt követően felült egy Debrecen felé tartó vonatra, majd szőrén-szálán eltünt. A szerkesztőségünkbe azonban Fülig Jimmy beküldött egy levelet, melyböl kiderül hová lett a magyar ponyvairodalom legnagyobb mestere. Sajnos Jimmy ezt a levelet olyan csúnya kézírással írta meg, hogy bizonyos szavakat képtelenek voltunk benne elolvasni. Arra kértük hát olvasóinkat, jöjjenek el a Debreceni Irodalom Házába, keressék meg a hiányzó betüket a kiállítótérben, hogy kiegészíthessük Fülig Jimmy levelét és így megtaláljuk az eltünt írót." (www.derimuzeum.hu) Mivel a foglalkozás egy hiányos szövegre épít és feladatok sorozatán át juttatja el a látogatót a megoldásig, Rejtő Jenő búvóhelyéig, így lehetöségünk adódott végigkövetni azt a folyamatot, ami révén a látogató feldolgozza a kiállítást. „A kiállításokról nyert visszajelzésekből kiderül, hogy nemcsak a müalkotás, hanem a kiállítás maga is sokféle gondolatot és érzést kelthet, $\mathrm{s}$ ezek némelyike éppen ellentétes azzal, ami a rendezők szándéka volt.” (Kárpáti és Vásárhelyi, 2013) A játék révén próbáltuk a kiállítás értelmezésének sokféle lehetőségét egy mederbe terelni, és segíteni a látogatókat, 
hogy úgy fogadják be a kiállítást, ahogy azt a rendezők szándéka diktálta, s ezáltal a kiállítással közvetített üzenetet megértett üzenetté formálni.

Pedagógiai módszerként a játékosítást választottuk, mert úgy véltük, ez felel meg leginkább mind a kiállítás tematikájának, mind a 21. századi látogatói elvárásoknak. Ez a módszer nem más, mint "...játékalapú müködési elvek, játékesztétika, és játéktervezői gondolkodás használata emberek lekötésére, cselekvésre sarkallására, tanulásának elősegítésére és problémák megoldására." (Kapp 2012: 10)

Ahhoz, hogy minél jobban sikerüljön a látogatókat motiválni, és Rejtő Jenő müveinek világába bevonni, a kiállításban elhelyezett életnagyságú standee-ket felhasználva Rejtő karakterekkel játszottunk. Ök üzentek, vagy épp kértek segítséget a játékosoktól.

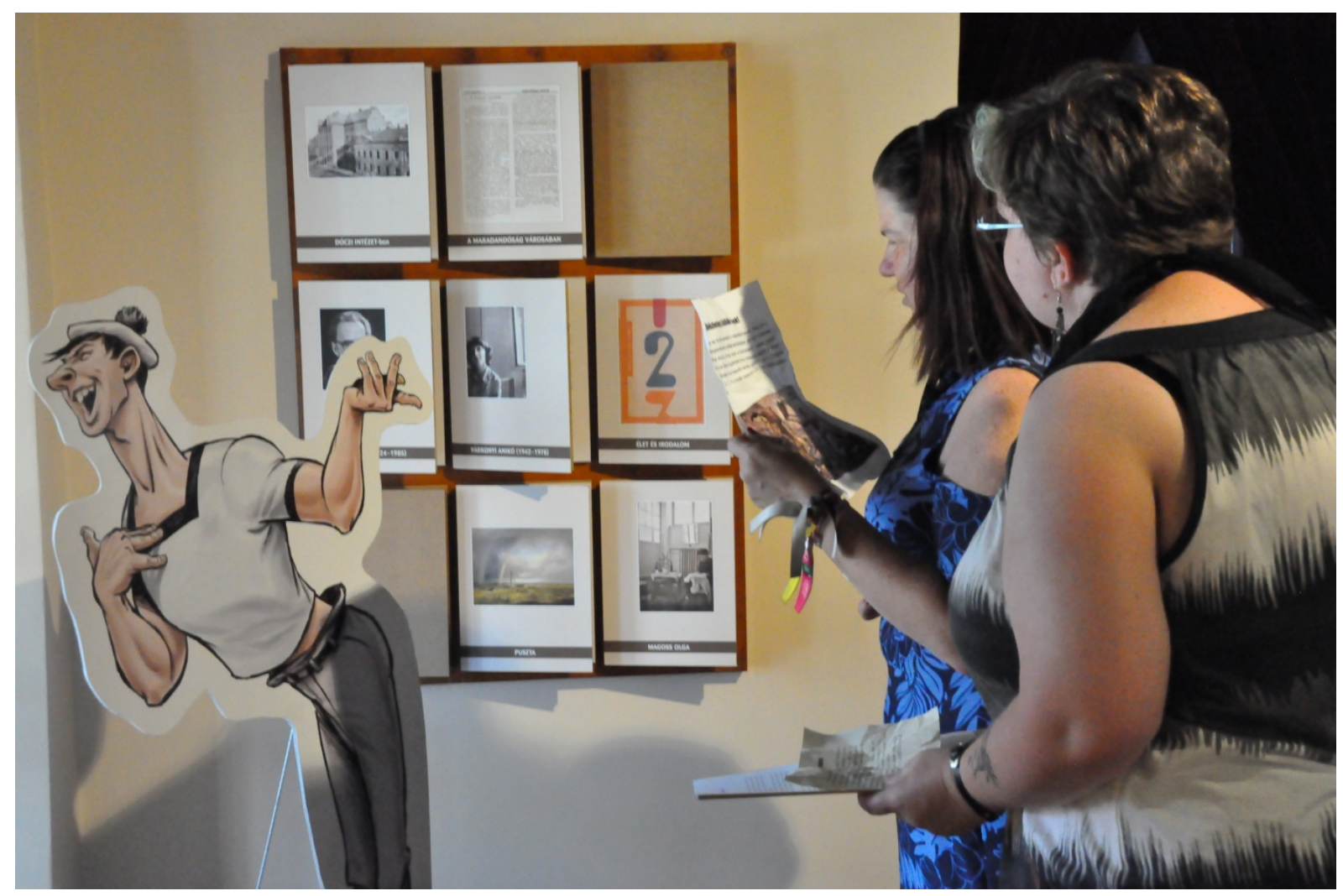

2.kép. REJTÖzködő Irodalom címü időszaki kiállitás. Fotó: Aranyi Fruzsina

A foglalkozás során a múzeum, mint egy külön Rejtői világ jelent meg, amiben a kiállított tárgyak tudományos értékük megtartása mellett a játék szövevényét képezik. Külön izgalmat kelthetett a tény, hogy olyan kultikus tárgyak jelenlétében került sor a nyomozásra, mint az állandó kiállítás részét képező Csokonai Vitéz Mihály furulyája, vagy Lilla gyürüje, annak ellenére is, hogy ezek a tárgyak nem képezték a nyomozás szerves részét. A látogató egy olyan foglalkozás részese lett, ami a rejtői regényvilág határán állt. A karakterek, és a történet kezdete megfelelt a kánonba foglaltaknak, de a történet vége kitaláció volt, így azok számára is izgalmassá vált a nyomozás, akik olvasták az író regényeit. A foglalkozás igyekezett széles körü tudással gazdagítani minden látogatói réteget úgy, hogy a játékosan szerzett új ismeretanyag szinte észrevétlenül épült be a már meglévő ismereteik közé. (Csíkszentmihályi, 1997) 
A nyomozás egy fiktív nyomtatvány, a REJTÖzködő Irodalom című újság különkiadásával indult, s végig fontos szerepet töltött be a nyomozásban, s egyszersmind a tudásszerzésben. Az újság a valós életrajzi adatokat összekötötte a fikcióval. Címlapján közöltük azt a fényképet, amin Rejtő Jenő Karinthy Frigyes és Salamon Béla társaságában szerepel. Ha nem is a fénykép elkészülése utáni másnap és nem is Debrecenben, az minden esetre életrajzi tény, hogy Rejtő Jenő életében többször is eltünt. Elöre eltervezett akció volt ez részéről annak érdekében, hogy népszerüsítse írói munkásságát. Így a játék nem csak a rejtői világból emelt át szereplőket és eseményeket, hanem az író életéből is, s így végig valóság és kitaláció határán ingadozott, és a játékvezető múzeumpedagógus narrációja révén vált csak szét a látogató tudatában a kettő. Az újság kiemelt funkciója volt, hogy Fülig Jimmy rejtői regényvilágra alapozott fiktív levelének közlésével segítséget nyújtson a látogatóknak az író megtalálásában.

A játék szereplői levelek segítségével kommunikáltak a látogatókkal. A levelek szövegeinek megformálásakor igyekeztünk megtartani a rejtői karakterek egyéni stílusát úgy, hogy a levelek szövege nyomravezetö jelentést hordozzon. A különböző médiumok, a hang, a kép és a szöveg egymást erősítő módon kaptak szerepet a kiállításban, s ezáltal a játékban is.

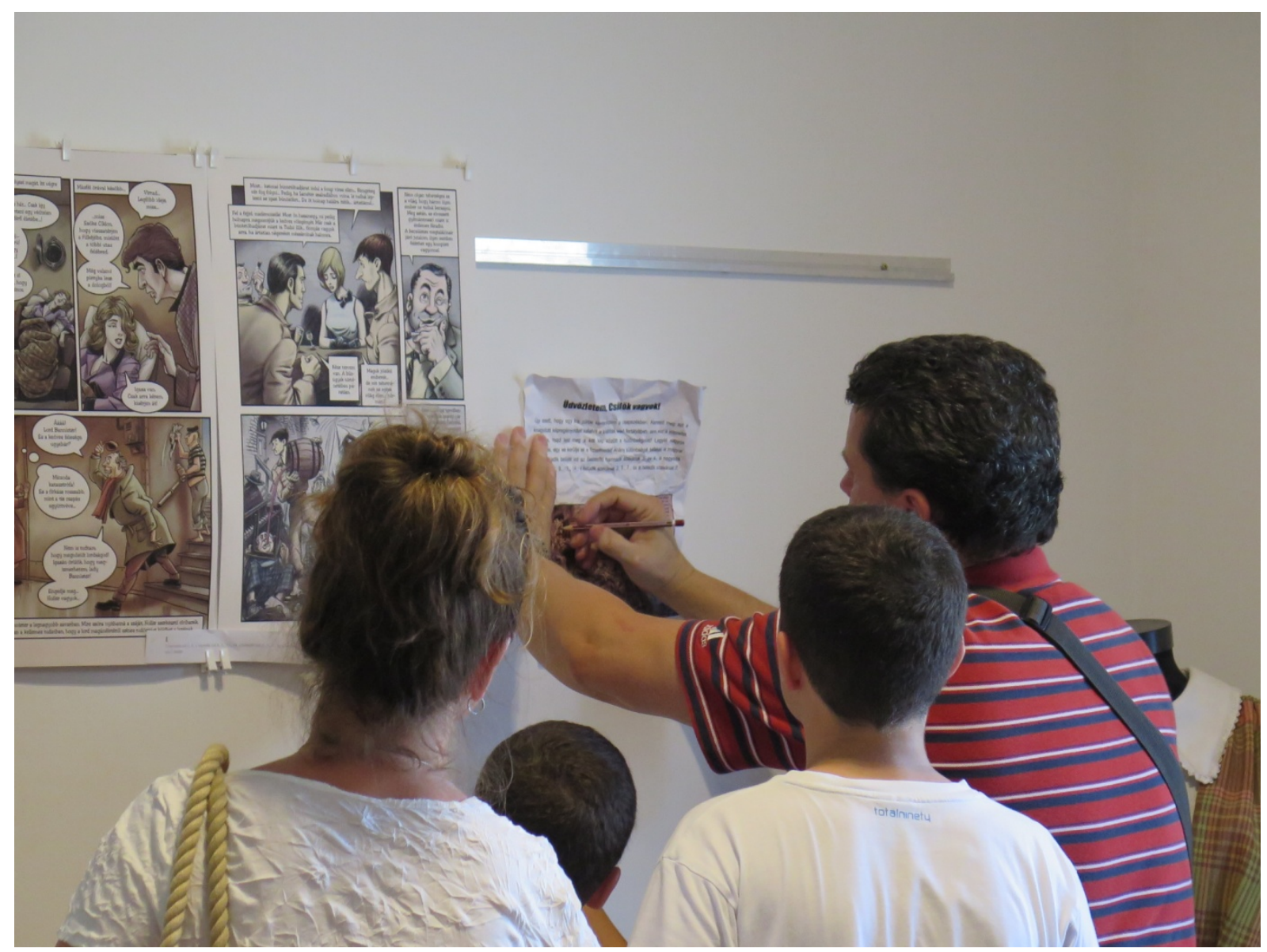

3.kép. REJTÖzködö Irodalom címü időszaki kiállitás. Fotó: Aranyi Fruzsina

A nyomozást három fázisra lehetett tagolni és eredményessége ezen fázisokban történő tanulás eredményességétől függött. A három fázis egy az egyben megfeleltethető az IPOOmodell fázisainak. A továbbiakban elöbb ismertetjük a modellt, majd a modell tükrében 
megvizsgáljuk a kiállítás befogadásának hatékonyságát, amire jelen esetben, mint a tanulás hatékonyságára tekintünk.

\section{Múzeumpedagógiai foglalkozás az IPOO-modell tükrében}

Az IPOO empirikus kutatás nyomán kidolgozott módszer a tanulás hatékonyabbá tétele érdekében. A modell a tanulásra, mint információfeldolgozásra tekint. Így megkülönböztethetjük az információgyüjtés, az input, az információfeldolgozás, a process, az információ alkalmazás, az output és ezek hatékonyságát meghatározó tanulásszervezést, az organizációt. Az elmélet szerint a tanulás az információkezelés fázisainak nyomán megy végbe. Azonban a tanulásszervezés az azt megelöző három szakasz összegét meghatványozza. Ebböl fakadón sem az első három fázis megfelelö sorrendje, sem a tanulásszervezés nem elhanyagolható, ha azt szeretnénk, hogy hatékony tanulás menjen végbe.

A tanulási problémák a modell minden fázisában jelentkezhetnek. Az input fázisban probléma adódhat a témaválasztással, a forráskutatással, illetve az információforrások használatával. A Hová tünt Rejtő Jenő? címü múzeumi nyomozás a korábban ismertetett szerkezeti és tartalmi jellegezetességei révén a forráskutatás és az információforrások használatával kapcsolatos problémák meglétére mutathat rá. A nyomozás az információ felkutatására aktivizálja a látogatót. A felkutatásban nehézséget jelenthet az ismeretlen helyszín, a tér tagoltsága, az állandó kiállítás és az időszaki kiállítás elkülönítése, az időszaki kiállítás töredékessége, valamint az eltérő infomációhordozó felületek feltérképezése. A process fázisban probléma jelentkezhet az információfeldolgozással. A múzeumepdagógiai foglalkozás során a látogatók logikai és asszociációs képességei aktivizálódnak. Azonban a memorizálással kapcsolatos tanulási problémák diagnosztizálására nem alkalmas. A nyomozás során betűket keresünk, memorizálásra nincs szükség a feladatok megoldásához, a nyomozást követően pedig a direkt és indirekt módon szerzett tudás ellenőrzésére nincs lehetőség. Az output fázisban szóbeli output problémát szintén nem diagnosztizálhatunk a foglalkozás alatt, mert a szóbeli megnyilvánulás a nyomozás során nem releváns. Az írásbeli output már ennél sokkal markánsabban van jelen. A feladatok megoldásában és a nyomozás állásának dokumentálásában érhető tetten. Szintén jól megfigyelhető a viselkedéses outputban jelentkező esetleges problémák a keresgélés és a gyakorlati feladatok teljesítése során.

Az organizációval kapcsolatos tanulási problémák jelentkezhetnek a tanulás helyszínével kapcsolatban. Ez a REJTÖzköző Irodalom időszaki kiállítás esetében a tér szerkezete és az állandó kiállítás egyidejű jelenléte miatt fokozottan megjelenhet. Szintén jelentkezhet a tanulás időbeosztásával kapcsolatos probléma, de ez csak kirívó esetben érzékelhető a múzeumpedagógus számára, mivel korlátlan játékidő áll a látogatók rendelkezésére. Jelentkezhet a tanulás időbeosztásával kapcsolatos probléma is. A játék struktúrájából adódóan a tanulási folyamat összerendezése a múzeumpedagógus által kialakított játékmechanizmus által előre adott. A látogatónak lehetősége van egy lineáris játék helyett bárhol elkezdeni és befejezni a játékot. A forgatókönyv rugalmas volta révén kiküszöbölhetők a tanulási folyamat összerendezésével kapcsolatos problémák. Végezetül a modell szerint a tanulás finanszírozásával kapcsolatban is felmerülhetnek problémák, de ez egy ingyenes múzeumpedagógiai foglalkozás esetén szintén nem releváns.

Az IPOO-modellben az input (esetünkben az állandó és a ráépült időszaki kiállítás által közvetített tartalom) és az output (a sikeres nyomozás) ismeretében háromféle információfeldolgozási módról beszélhettünk. Deficites tanulás során információvesztés történik. Ekkor a látogató nem talál meg maradéktalanul minden direkt információt a kiállításban, az indirekt információk feltárására pedig nem törekszik. Ismeretei atomisztikusak, nem szerveződnek holista ismeretrendszerré. Reproduktív tanulás során a tartalom jóformán feldolgozás nélkül kerül visszaadásra. Ez esetben nem beszélhetünk 
lényegi kiemelésről. A látogató az indirekt információk kikövetkeztetésére nem törekszik. Ismeretei atomisztikusak, nem állnak össze holisztikus rendszerré. A nyomozás ok-okozati összefüggések keresésére, gondolattársításokra ösztönzik a látogatót. Ennél fogva segíti a kreatív, alkotó tanulás végbemenetelét, aminek eredményeképp a látogató többet fog tudni, mint amennyi információt a kiállításban megjegyzett. Az információk feldolgozásával és alkalmazásával látni fogja az összefüggéseket, és újonnan szerzett tudását kapcsolni tudja már meglévő ismereteihez. A múzeumi nyomozás a produktív tanulás során hozzásegíti a látogatókat az információk lényegkiemelésen alapuló megtalálásához, az indirekt információk feltárásához, és az ismeretek holista ismeretrendszerré szervezéséhez.

A modell által nyújtott szemléletmód segítségével könnyen felfedezhetők a különböző fázisokban felmerülő problémák. Az egyes fázisokban nyújtott látogatói teljesítmény pedig erösítheti vagy gyengítheti egymást.

Egy-egy múzeumpedagógiai foglalkozás során, amennyiben az feladatlappal, vagy a diákok számára sokkal izgalmasabb formában játékosított módszerrel történik, lehetőség adódik a diagnosztika elvégzésére. A diákoknak ugyanis mozgósítaniuk kell a kiállításban a foglalkozás során szerzett megfigyeléseiket, ismereteiket és alkalmazniuk is kell tudásukat. Ha a múzeumpedagógus szakember folyamatosan monitorozza a látogatók elöre haladását a játékban, látja hol adódnak problémák, min kellene fejleszteni.

Sokkal hatékonyabb és koncentráltabb fejlesztésről beszélhetünk természetesen abban az esetben, ha nem csak egyszeri látogatásról beszélünk, hanem ha az adott látogatói csoport változatlan összetételben, szervezett formában máskor is igényel múzeumpedagógiai foglalkozást. Ebben az esetben elöre egyeztetett formában koncentrált tanulásszervezés valósulhat meg. A modell lehetővé teszi, hogy a múzeumok egy magasabb szinten is bekapcsolódhassanak a tanulás hatékonyságának fejlesztésébe, és nem csak az unikális tárgyak megjelenési színterei legyenek.

A REJTÖzködő Irodalom címü időszaki kiállításhoz kapcsolódó múzeumpedagógiai foglalkozással igyekeztünk minél szélesebb látogatói réteget megszólítani. Foglalkozásunkat a legkisebbektől egészen a legnagyobbakig minden korosztálynak ajánlottuk, amennyiben családdal érkeztek, ahol az idősebb generáció segítheti a nyomozásban a fiatalabbakat, és átvállalhatnak tölük olyan feladatokat, amiket életkorukból adódóan nem tudnának elvégezni. Iskolai csoportoknak 3. osztályosoktól egyetemistákig ajánlottuk a foglalkozást, mert a diákok ekkortól írnak és olvasnak biztonsággal. Számítottunk rá, hogy ez az életkorában széles látogatói réteg a kiállítás témájáról eltérő ismeretanyaggal bír, s ezáltal tudásszintje is más.

A holisztikus ismeretrendszer szerveződési modellje alapján a 0 . szinten a látogatóknak nincs az adott témáról ismerete. Rejtő Jenő választható tananyagként szerepel a kerettantervben, így a diákok jelentős része nem, vagy csak szüleitől hallott az íróról, müveit pedig egyáltalán nem ismerte. Foglalkozásunk összeállítása során törekedtünk rá, hogy a különböző tudásszinttel rendelkező látogatók mind élvezzék a nyomozást. Így azokat, akik nem rendelkeztek ismerettel az íróról, a foglalkozás információkhoz segítette. A holisztikus tudás 1. szintjén a látogatók elszeparált információmorzsákkal rendelkeznek. A 2. szintjén a látogató tudását képes témakörökbe csoportosítani. A 3. szintjén az azonos témakörbe tartozó ismeretek között képes meglátni az összefüggéseket. A 4. szintjén az azonos tudományterületbe tartozó témakörök között megtalálja az összefüggéseket.

Játékosított múzeumpedagógiai foglalkozásunk azt a célt tűzte ki maga elé, hogy segítse a látogatókat meglévő tudásuk rendszerezésében, és újakkal való kiegészítésében. Azoknál a látogatóknál pedig, akiknek a tudása olyan szintü, segítse a holisztikus tudás kialakulását, hogy meg tudják találni az összefüggéseket a különböző tudományterületek között, össze tudják kapcsolni a formális oktatásban a különböző tantárgyak tanulásakor szerzett 
ismereteiket, és képes legyenek ezeket kiegészíteni a kiállításban szerzett új információkkal. (Mezö, 2011)

\section{IRODALOM}

Aranyi Fruzsina (2017): Gamifikáció bevezetése informatikai eszközök támogatásával nonformális oktatási formát alkalmazva múzeumi környezetben. Informatika a felsőoktatásban 2017 tanulmánykötet, Debrecen.

Csíkszentmihályi Mihály (1997): A fow - az áramlat. A tökéletes élmény pszichológiája. Akadémiai Kiadó, Budapest.

Déri Múzeum honlapja www.derimuzeum.hu (utolsó letöltés: 2018.01.26.)

Janes, Robert R (2009): Museums in a Troubled World - Renewal, Irrelevance or Collapse?, Taylor and Francis.

Káldy Mária, Kárpáti Andrea, Szirmai Anna Lidia (2010): Helyzetkép és perspektívák Múzeumpedagógia Magyarországon 2008 - 2009. Szabadtéri Néprajzi Múzeum Múzeumi Oktatási és Képzési Központ, Szentendre.

Kapp, K. M (2017):: The Gamification of Learning and Instruction: Game-based Methods and Strategies for Training and Education. San Francisco, CA: Wiley, 2012; In: Formann Richárd: Játékoslét - A gamifikáció világa. Typotex, Budapest. 109.p.

Kárpáti Andrea és Vásárhelyi Tamás (2013): Kiállítási kommunikáció - Tudomány - kiállítás - kommunikáció, ELTE TTK, Budapest. http://ttktamop.elte.hu/onlinetananyagok/kiallitasi_kommunikacio (utolsó letöltés: 2018.01.26.)

Kerettantervek, 2012 http://kerettanterv.ofi.hu/ (utolsó letöltés: 2018.01.26.)

Lakner Lajos (2013): Vezetö a Debreceni Irodalom Háza Álmodó magyarok állandó kiállitásához, Déri Múzeum, Irodalmi Tár, K.X.2018.2.1.

Mező Ferenc (2011): Tanulás: diagnosztika és fejlesztés az IPOO-modell alapján. $\mathrm{K}+\mathrm{F}$ Stúdió Kft., Debrecen.

Nemzeti alaptanterv, 1995 http://www.nefmi.gov.hu/kozoktatas/archivum/nemzetialaptanterv (utolsó letöltés: 2018.01.26.)

Sz. Kürti Katalin (2006): Vezetö a debreceni Medgyessy Ferenc Emlékmúzeum Medgyessy Ferenc (1881-1958) életmü-kiállitásához. Déri Múzeum, Debrecen. 